DOI 10.21685/2500-0578-2020-3-3

\title{
MOTION AS A FUNDAMENTAL BASIS OF LIFE
}

\section{A. P. Geraskina', O. V. Smirnova', V. F. Antoschenkov', N. A. Leonova ${ }^{3}$, V. N. Korotkov ${ }^{4}$, A. V. Gornov ${ }^{1}$}

${ }^{1}$ Center for Forest Ecology and Productivity RAS of the Russian Academy of Sciences, 84/32 Profsoyuznaya street, Moscow, 117485, Russia E-mail: angersgma@gmail.com

${ }^{2}$ Smolensk State University, 4 Przhevalsky street, Smolensk, 214000, Russia

E-mail: irinalife10@mail.ru

${ }^{3}$ Penza State University, 40 Krasnaya street, Penza, 440026, Russia

E-mail:na_leonova@mail.ru

${ }^{4}$ Institute of global climate and ecology named after academician Yu. A. Israel, 20B Glebovskaya street, Moscow, 107258, Russia E-mail:korotkovv@list.ru

Abstract. This commentary is devoted to the article by V. G. Gorshkov and A. M. Makaryeva (2020), in which the division of biota in forest ecosystems is considered using the concepts of both "immotile life" and "locomotive life". The article presents well-known arguments to prove the erroneousness of using such concepts, because motion is a fundamental property of living creatures and is realised at all levels of living system organisation. Representatives of all the kingdoms are widely distributed in space at different stages of the life cycle. In opposite the view by Gorshkov and Makarieva (2020), which the large herbivorous are destroyers of terrestrial ecosystems emphasizes, in the current commentary is considered the importance of mammals in forests, for the circulation of matter and energy flow in forest ecosystems to maintain biodiversity and the efficiency of trophic systems.

Keywords: biodiversity, ecological pyramid, cycle of matter, forest, terrestrial ecosystem, phytophages, megafauna.

Acknowledgments. The research was carried out within the framework of the State Task of the Center for Problems of Ecology and Productivity of Forests, Russian Academy of Sciences AAAA-A18-118052590019-7, with the financial support of the Russian Foundation for Basic Research (19-04-00-609 A).

For citation: Geraskina A. P., Smirnova O. V., Antoschenkov V. F., Leonova N. A., Korotkov V. N., Gornov A. V. Motion as a fundamental basis of life. Russian Journal of Ecosystem Ecology. 2020;5(3). Available from: https://doi.org/10.21685/2500-0578-2020-3-3

\section{АВИЖЕНИЕ КАК ФУНААМЕНТАЛЬНАЯ ОСНОВА ЖИЗНИ}

\section{А. П. Гераськина', О. В. Смирнова', В. Ф. Антощенков², Н. А. Леонова ${ }^{3}$, В. Н. Коротков ${ }^{4}$, А. В. Горнов ${ }^{1}$}

\author{
${ }^{1} Ц$ ентр по проблемам экологии и продуктивности лесов Российской Академии наук, \\ Россия, 117997, г. Москва, ул. Профсоюзная, 84/32 \\ E-mail: angersgma@gmail.com \\ ${ }^{2}$ Смоленский государственный университет, Россия, 214000, Смоленск, ул. Пржевальского, 4. \\ E-mail: irinalife10@mail.ru \\ ${ }^{3}$ Пензенский государственный университет, Россия, 440026, Пенза, ул. Красная, 40. \\ E-mail:naleonova@mail.ru \\ ${ }^{4}$ Институт глобального климата и экологии имени академика ю. А. Израэля, Россия, 107258, Москва, ул. Глебовская, 20Б \\ E-mail:korotkovv@list.ru
}

Аннотация. Настоящий комментарий посвящен статье В. Г. Горшкова и А. М. Макарьевой (2020), в которой разделение биоты в лесных экосистемах рассматривается с использованием понятий как «неподвижная жизнь», так и «передвигающаяся жизнь». В статье представлены известные аргументы в пользу ошибочности использования подобных представлений, поскольку движение является фундаментальным свойством живых существ и реализуется на всех уровнях организации живых систем. Представители всех царств природы широко расселяются в пространстве на разных стадиях жизненного цикла. Подчеркивается важная экологическая роль в лесах крупных растительноядных млекопитающих (которые в статье В. Г. Горшкова и А. М. Макарьевой (2020) рассматриваются как разрушители наземных экосистем), их необходимость для круговорота вещества и потока энергии в лесных экосистемах, поддержания биоразнообразия и эффективности трофических систем. 
Ключевые слова: биоразнообразие, экологическая пирамида, круговорот веществ, наземная экосистема, фитофаги, мегафауна.

Благодарности. Исследование выполнено в рамках Государственного задания Центра по проблемам экологии и продуктивности лесов Российской академии наук АААА-А18-118052590019-7 при финансовой поддержке Российского фонда фундаментальных исследований (19-04-00-609 A)

Biology, as a science of living Nature, considers motion as the entire set of processes occurring in organisms - from the transmembrane transfer of ions in cells to the motion of an individual in an open area. In this case, motion in space occurs in different ways: as a result of growth and development of an individual in the process of ontogenesis (growth of roots, shoots in higher plants); when organisms interact with environmental factors (tropisms in plants, taxis in bacteria and animals); passive motion with the help of water and wind (bacteria, fungal spores, pollen and plant seeds) and with the help of animals (i.e. African elephants are the only modern species that spread the seeds of more than a dozen tropical species of woody plants) (Fig. 1) [1-3]; active motion with the help of special organs - pseudopodia, cilia and flagella (bacteria, unicellular and some multicellular animals, lower plants), with the help of special outgrowths of skin coverings and the contractile activity of muscles (invertebrates); and with the help of a musculoskeletal system controlled by the central nervous system and including the internal skeleton, muscles and specialised limbs (vertebrates).
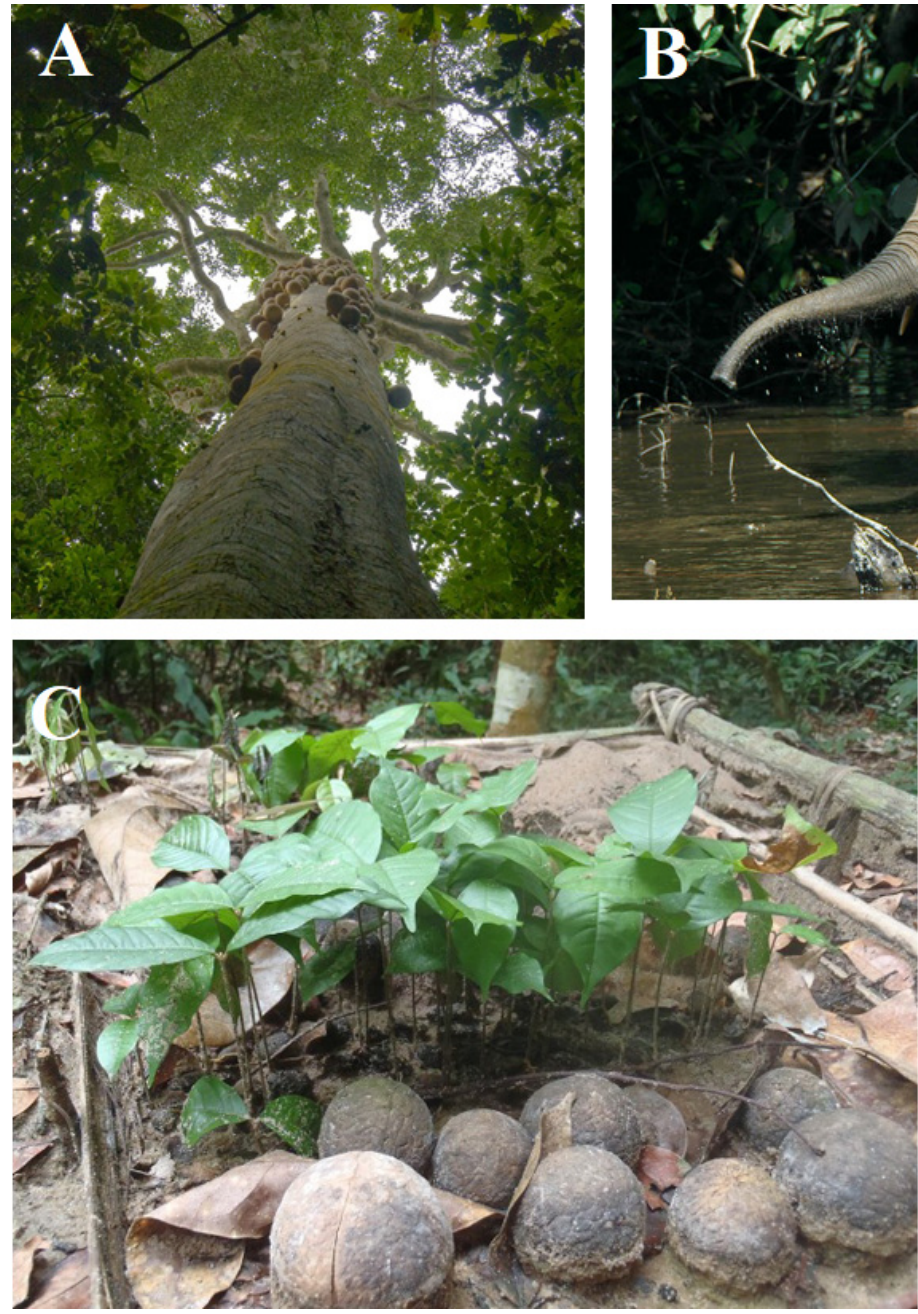
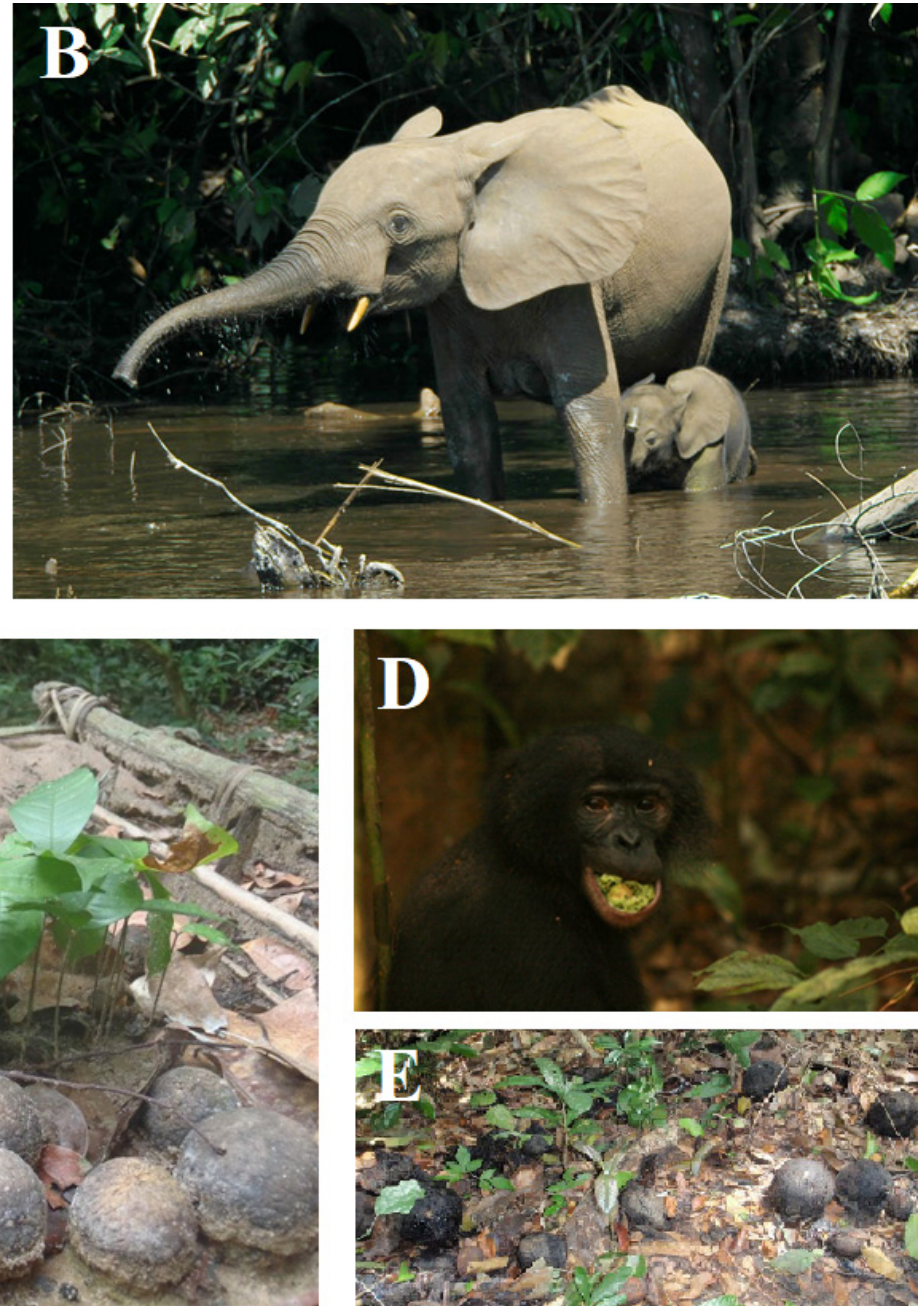

Fig. 1. Megafauna involved in distributing tropical tree seeds [3]:

A - a tree from the genus Omphalocarpum (Congo rainforest) with large fruit on the trunk. The seeds of the tree are spread only by elephants because the fruit are very tightly attached to the trunks and can only be torn off with the great effort of large animals. Photo by David Beaune; $B$ - forest elephants in the Mbeli River, Nouabalé Ndoki National Park, Congo. Photo by Thomas Breuer; $C$ - seeds, fruit and seedlings of Poga oleosa, the seeds of which are carried by elephants. Photo by David Beaune;

$D$ - the seeds scattered by forest elephants are too large to be swallowed by other animals, such as the bonobo (Pan paniscus), one of which is shown feeding on Parinari excelsa fruit. Photo by David Beaune; $E$ - Mammea africana fruit rot on the ground without scattering. Photo by David Beaune 
The concept of immotile life [4] is unacceptable for biology and, indeed, science as a whole because it contains a contradiction - motion is a fundamental property of living things. Motion is a living base. Immotile life means the death of the organism - i.e. termination of its functions. The ability to move in space is a necessary condition and the main property of representatives of all the kingdoms of Nature; it can manifest itself unequally at different stages of ontogenesis, but it necessarily takes place during at least one stage of the life cycle. In bacteria, fungi and lower and higher spore plants, as a rule, the greatest ability to move over long distances is realised with the help of spores - specialised for the settlement and reproduction of cells, in seed plants - pollen grains (male gametophytes) and seeds, which can be transferred tens or even hundreds of kilometers from their parents. Animals, especially vertebrates, develop the ability to adequately move in area, as a rule, by an adult age. Invertebrates also actively settle in space at an adult age (the migration distances are certainly shorter than those of most vertebrates) and can also passively moving at the egg stage (with water currents, wind and when other animals migration).

The spaces that are colonised by plants and fungi through their growth and development are sometimes larger than that colonised by some animals during migrations. The mycelium of a mycorrhizal fungus can spread over hundreds of hectares; this phenomenon underscores why fungi are sometimes called the largest organisms on the planet [5]. The vegetative organs of a number of herbaceous plants - stolons and rhizomes - enable them to move in space over tens of metres or more in a year. An adult tree, due to its developed root system and crown, occupies a much larger volume in space than a large phytophage; the lifespan of woody species, as a rule, is several times longer than that of vertebrates. At the same time, the size and structural and functional organisation of the crown of a living tree continuously change in the course of ontogenesis, creating conditions for the settlement of various nesting birds at different times of the year. In addition, its living and falling foliage is a trophic resource and habitat for numerous litter micro-, meso- and macrofauna. A dead tree is a habitat for hollow-nesting birds, large bark beetles and the species accompanying them and other numerous invertebrates of myriad trophic groups [6].

Biosphere stability is maintained by the continuous flow of matter and energy, which is provided in ecosystems by organisms of different trophic levels [7]. In particular, forest ecosystems are including producers (autotrophic plants), consumers of different orders (heterotrophic phytophages and predators that regulate the number of phytophages) and decomposers (invertebrate saprophages, saprotrophic fungi and bacteria). The loss of biomass at each trophic level is about $10 \%$ (Lindemann's rule), that is, the biomass of all phytophages (from invertebrates to large mammals) in forests should be 10 times lower than that of autotrophic plants.

Gorshkov and Makarieva [4] controversially assert that "locomotive life" has an abundance of space and food. The ratio of producer biomass to all consumer biomass in natural ecosystems is quite stable. Violation of the required ratio between the constituent parts of the ecosystem does not reach a critical level and, due to the presence of negative feedbacks, the ecosystem returns to a stable state. It should be noted that plants capable of vegetative reproduction can restore the size of their population much faster than large mammals, which are K-strategists (species that stay near their carrying capacity) and never present sudden large increases in their numbers.

In most modern terrestrial ecosystems, the main biomass of animals comprises small arthropods with a short life cycle and soil organisms - ticks, springtails, annelids, etc. [8] - and it is they who consume most of the primary production, which is reflected in figure 5 of Gorshkov and Makarieva's work [4]. In this regard, it is clearly not true to call large mammals 'hot spots' of imbalance in synthesis and decomposition that pose a potential threat to the stability of ecosystems and the environment.

R. May (1981) quotes from P. J. Darlington's classic Zoogeography: The Geographical Distribution of Animals [9]: "Throughout the known history of vertebrates, in cases where the fossil data are sufficiently complete, it turns out that both the Earth as a whole and its individual parts were inhabited by the fauna of vertebrates, which remained fairly constant in size and adaptive structure. Neither the globe, nor one or another part of it were overpopulated by animals in one epoch and empty in another, and there were no such ecological niches that would remain unoccupied for a long time. There have always been (except, perhaps, very short periods of time) herbivores and carnivores, large and small forms, and many different less significant adaptive groups, all of which were represented in a certain ratio with each other. The same balance is observed in the existing faunas. The fauna of each continent generally corresponds to its area and climate, and in each main fauna there is a rational ratio of herbivores, predators, etc. It cannot be accidental".

According to Zherikhin (1993), maintenance of steppes and savannas is based on the co-evolution of grasses and large herbivorous mammals. It is 
known that the basis for the existence of these communities is a remarkable coadaptation of grasses and phytophages that dominate in the plant cover: grasses do not have effective protection against their consumption (thorns, poisonous substances, etc.), but they can compensate for the biting of aerial parts by a sharp acceleration of their regeneration (due to intercalary meristems, the function of which stimulates by the saliva of large phytophages in the process of biting). Therefore, regulation in such a community is achieved very simply: with a decrease in the pressure of phytophages, the primary production also automatically decreases - and vice versa. Mammals, primarily various ungulates and carnivores, play the main role in the grazing chains of these ecosystems $[10,11]$. The main features that characterise such grass biomes are: extremely high productivity, very fast turnover of organic matter and the presence of an easily mobilised reserve of this organic matter in unusually fertile soils (such as chernozem) [10].

In modern forest ecosystems, especially in the boreal forests of the Northern Hemisphere, large phytophagous mammals are few in number, mainly due to active extermination by humans in the early Holocene (primarily as a result of fire and driven by hunting and slash-and-burn agriculture) [1215]. As a result, pasture ecosystems transform into detrital ones [16], while modern soils in forests are considered the result of only microbial-plant interactions [17]. However, it has been proven many times that the absence of large mammals leads to a reduction in ecological forest niches: zoogenic glades; gaps; breakthroughs in the forest canopy, that is, those spaces that are inhabited by lightloving flora, where renewal becomes possible, including woody light-loving plant species; and trophic groups that feed on animal remains, i.e., coprophages and necrophages, which ensures the decomposition of excrement and animal carcasses one of the important links in the cycle of the substance necessary for the restoration of soil fertility [18], and, consequently, for the growth and development of the next generations of plants. The diversity of soil biota decreases and groups of taxa disappear; it will be extremely difficult to restore them over large areas even in the case of reintroduction of large phytophages into forests $[12,19]$. In the absence of large mammals, this is also ob- served when the regime of absolute nature conservation, which often leads to the formation of shady forests and a reduction in the species diversity of flora due to the loss of light-loving species [20, 21]. Intra- and intercenotic flows of plant diasporas are carried out mainly by birds [22] and small- and medium-sized mammals [22, 23]. However, in some cases, grazing is a necessary condition for maintaining certain plant species. Thus, in the lichen pine forests of the northern taiga, pine cannot be renewed with a well-developed lichen cover; its seedlings take root in places of intensive grazing by reindeer [24]. Based on the study of the influence of grazing on the pasture ecosystems of Serengeti, when isolated from the hoofed areas of the pastures as a result of their fencing, Themeda triandra, one of the common and well-eaten cereal species, practically disappears within 5 years. In Yellowstone National Park, the United States, elk and bison grazing areas were on average $47 \%$ more productive (in land production) than fenced areas [24]. In addition, the spread of seeds by large animals for tens and hundreds of kilometers protects plants from closely related crossbreeding, which provides the genetic basis for the adaptation of species to a constantly changing habitat.

Thus, in the absence of megafauna, taxonomic as well as functional diversity of forest ecosystems decreases. This decline slows down the cycle of matter, decreases the productivity of ecosystems and, ultimately, leads to their degradation. Polydominant forests with a clearly pronounced mosaic of habitats are being replaced by monodominant forests, most often shade-tolerant dark conifers, which are highly susceptible to fires, diseases caused by insect irruptions and the activity of pathogenic microorganisms.

In modern conditions of global environmental challenges (catastrophic degradation of ecosystems, withdrawal of primary production mainly by humans, climate change, etc.), biologically fundamental knowledge and ideas about the functioning of ecosystems should become the basis, including for mathematical calculations of biosphere processes. Real, and not hypothetical, ideas should serve as the basis for the restoration of communities and planning experiments for the reintroduction of lost species and functional groups in ecosystems.

\section{Библиографический список}

1. Forest elephants: tree planters of the Congo / S. Blake, S. L. Deem, E. Mossimbo, F. Maisels, P. Walsh // Biotropica. - 2009. - Vol. 41 (4). - P. 459-468.

2. Doom of the elephant-dependent trees in a Congo tropical forest / D. Beaune, B. Fruth, L. Bollache, G. Hohmann, F. Bretagnolle // Forest Ecology and Management. - 2013. - Vol. 295. - P. 109-117.

3. URL: https://news.mongabay.com/2013/03/seeing-the-forest-through-the-elephants-slaughtered-elephants-takingrainforest-trees-with-them/ 
4. Gorshkov, V. G. Key ecological parameters of immotile versus locomotive life / V. G. Gorshkov, A. M. Makarieva // Russian Journal of Ecosystem Ecology. - 2020. - Vol. 5 (1). - DOI 10.21685/2500-0578-2020-1-1.

5. Stamets, P. The role of mushrooms in nature / P. Stamets // The overstory book: cultivating connections with trees / ed. by C. R. Elevitch. $-2^{\text {nd }}$ ed. - Holualoa, Hawaii : Permanent Agriculture Recources, 2004. - P. 74-80.

6. The afterlife of tree / ed. by A. Bobiec, B. Jaroszewicz, A. Szymura, K. Zub. - Warszawa-Hajnowka, 2005 . - 252 p.

7. Вернадский, В. И. Биосфера и ноосфера / В. И. Вернадский. - Москва : Наука, 1989. - 261 с.

8. Уиттекер, Р. Сообщества и экосистемы / Р. Уиттекер. - Москва : Прогресс, 1980. - 328 с.

9. Эволюция экологических систем / Э. Майр, Ф. Айала, Р. Дакерсон, У. Шопф, Дж. Валентайн, Р. Мэй, Дж. Мэйнард Смит, Ш. Уошберн, Р. Левонтин // Эволюция. - Москва : Мир, 1981. - С. 173-193.

10. Жерихин, В. В. Генезис травяных биомов / В. В. Жерихин // Экосистемные перестройки и эволюция биосферы. - Москва : Недра, 1994. - С. 132-137.

11. Еськов, К. Ю. Удивительная палеонтология: История Земли и жизни на ней / К. Ю. Еськов. - Москва : НЦ ЭНАС, 2008. - $312 \mathrm{c}$.

12. Восточноевропейские леса: история в голоцене и современность / отв. ред. О. В. Смирнова. - Москва : Наука, 2004. - Кн. 1. - 479 с.

13. Смирнова, О. В. Современная зональность Восточной Европы как результат преобразования позднеплейстоценового комплекса ключевых видов / О. В. Смирнова, В. Н. Калякин, С. А. Турубанова, М. В. Бобровский // Мамонт и его окружение: 200 лет его изучения. - Москва : Геос, 2001. - С. 200-208.

14. Калякин, В. Н. О динамике распада мамонтовой фауны севера Евразии / В. Н. Калякин, С. А. Турубанова // Бюллетень Московского общества испытателей природы. Отдел биологический. - 2003. - Т. 108 (4). C. $10-19$.

15. Kalyakin, V. N. The origin and development of the eastern european taiga in late cenozoic / V. N. Kalyakin, S. A. Turubanova, O. V. Smirnova // Russian Journal of Ecosystem Ecology. - 2016. - Vol. 1 (1). DOI 10.21685/2500-0578-2016-1-2.

16. Smirnova, O. V. The concept "complementarity" as the basis for model and nature reconstruction of potential biota in the current climate / O. V. Smirnova, A. P. Geraskina, A. A. Aleynikov // Russian Journal of Ecosystem Ecology. - 2018. - Vol. 3 (3). - DOI 10.21685/2500-0578-2018-3-1.

17. Семенов, А. М. Диагностика здоровья и качества почвы / А. М. Семенов, В. М. Семенов, Б. А. Ван // Агрохимия. - 2011. - № 12. - С. 4-20.

18. Одум, Ю. Экология / Ю. Одум. - Москва : Мир, 1986. - Т. 1. - 328 с.

19. Гераськина, А. П. Влияние реинтродукции зубров на комплексы дождевых червей национального парка «Орловское Полесье» / А. П. Гераськина, Л. Л. Киселева, А. П. Карпачев, М. Н. Абадонова // Russian Journal of Ecosystem Ecology. - 2018. - Vol. 3 (4). - DOI 10.21685/2500-0578-2018-4-4.

20. Сукцессионные процессы в заповедниках России и проблемы сохранения биологического разнообразия / О. В. Смирнова, Л. Б. Заугольнова, О. И. Евстигнеев, В. Н. Коротков, Л. Г. Ханина и др. ; под ред. О. В. Смирновой, Е. С. Шапошникова. - Санкт-Петербург : Российское ботаническое общество, 1999. $549 \mathrm{c}$.

21. Оценка и сохранение биоразнообразия лесного покрова в заповедниках европейской России / О. В. Смирнова, Л. Б. Заугольнова, Л. Г. Ханина, М. В. Бобровский, В. Н. Коротков, О. И. Евстигнеев, Н. А. Торопова, В. Э. Смирнов, С. А. Шепелева, О. В. Пчелинцева, А. В. Славгородский, Е. М. Глухова, Е. В. Пономаренко, Е. С. Есипова, Г. Ю. Офман, А. М. Романовский, Е. П. Сарычева. - Москва : Научный мир, 2000. - 196 с.

22. Евстигнеев, О. И. Сойка (Garrulus glandarius) и зоохория в лесных сообществах (на примере НеруссоДеснянского полесья) / О. И. Евстигнеев, И. А. Мурашев, М. С. Романов // Russian Journal of Ecosystem Ecology. - 2018. - Vol. 3 (1). - DOI 10.21685/2500-0578-2018-1-1.

23. Evstigneev, O. I. Phytocenotic portrait of the european badger / O. I. Evstigneev, O. V. Solonina // Russian Journal of Ecosystem Ecology. - 2020. - Vol. 5 (1). - DOI 10.21685/2500-0578-2020-1-3.

24. Онипченко, В. Г. Функциональная фитоценология: Синэкология растений : учеб. пособие / В. Г. Онипченко. - 2-е изд. - Москва : КРАСАНД, 2014. - 576 с.

\section{References}

1. $\quad$ Blake S., Deem S. L., Mossimbo E., Maisels F., Walsh P. Biotropica. 2009, vol. 41 (4), pp. $459-468$.

2. Beaune D., Fruth B., Bollache L., Hohmann G., Bretagnolle F. Forest Ecology and Management. 2013, vol. 295, pp. 109-117.

3. Available at: https://news.mongabay.com/2013/03/seeing-the-forest-through-the-elephants-slaughtered-elephantstaking-rainforest-trees-with-them/

4. Gorshkov V. G., Makarieva A. M. Russian Journal of Ecosystem Ecology. 2020, vol. 5 (1). DOI 10.21685/25000578-2020-1-1.

5. Stamets P. The overstory book: cultivating connections with trees. 2nd ed. Holualoa, Hawaii: Permanent Agriculture Recources, 2004, pp. 74-80.

6. The afterlife of tree. Ed. by A. Bobiec, B. Jaroszewicz, A. Szymura, K. Zub. Warszawa-Hajnowka, 2005,252 p. 
7. Vernadskiy V. I. Biosfera i noosfera [Biosphere and noosphere]. Moscow: Nauka, 1989, 261 p. [In Russian]

8. Uitteker R. Soobshchestva i ekosistemy [Communities and ecosystems]. Moscow: Progress, 1980, 328 p. [In Russian]

9. Mayr E., Ayala F., Dakerson R., Shopf U., Valentayn Dzh., Mey R., Meynard Smit Dzh., Uoshbern Sh., Levontin R. Evolyutsiya [Evolution]. Moscow: Mir, 1981, pp. 173-193. [In Russian]

10. Zherikhin V. V. Ekosistemnye perestroyki i evolyutsiya biosfery [Ecosystem rearrangements and evolution of the biosphere]. Moscow: Nedra, 1994, pp. 132-137. [In Russian]

11. Es'kov K. Yu. Udivitel'naya paleontologiya: Istoriya Zemli i zhizni na ney [Amazing paleontology: history of the Earth and life on it]. Moscow: NTs ENAS, 2008, 312 p. [In Russian]

12. Vostochnoevropeyskie lesa: istoriya $v$ golotsene $i$ sovremennost' [East European forests: history in the Holocene and modern times]. Execut. ed. O. V. Smirnova. Moscow: Nauka, 2004, bk. 1, 479 p. [In Russian]

13. Smirnova O. V., Kalyakin V. N., Turubanova S. A., Bobrovskiy M. V. Mamont i ego okruzhenie: 200 let ego izucheniya [The mammoth and its environment: 200 years of studying it]. Moscow: Geos, 2001, pp. 200-208. [In Russian]

14. Kalyakin V. N., Turubanova S. A. Byulleten' Moskovskogo obshchestva ispytateley prirody. Otdel biologicheskiy [Bulletin of Moscow Society of Naturalists. Biological series]. 2003, vol. 108 (4), pp. 10-19. [In Russian]

15. Kalyakin V. N., Turubanova S. A., Smirnova O. V. Russian Journal of Ecosystem Ecology. 2016, vol. 1 (1). DOI 10.21685/2500-0578-2016-1-2.

16. Smirnova O. V., Geraskina A. P., Aleynikov A. A. Russian Journal of Ecosystem Ecology. 2018, vol. 3 (3). DOI 10.21685/2500-0578-2018-3-1.

17. Semenov A. M., Semenov V. M., Van B. A. Agrokhimiya [Agrochemistry]. 2011, no. 12, pp. 4-20. [In Russian]

18. Odum Yu. Ekologiya [Ecology]. Moscow: Mir, 1986, vol. 1, 328 p. [In Russian]

19. Geras'kina A. P., Kiseleva L. L., Karpachev A. P., Abadonova M. N. Russian Journal of Ecosystem Ecology. 2018, vol. 3 (4). DOI 10.21685/2500-0578-2018-4-4.

20. Smirnova O. V., Zaugol'nova L. B., Evstigneev O. I., Korotkov V. N., Khanina L. G. et al. Suktsessionnye protsessy $v$ zapovednikakh Rossii i problemy sokhraneniya biologicheskogo raznoobraziya [Successional processes in Russian nature reserves and problems of maintaining biological diversity]. Saint-Petersburg: Rossiyskoe botanicheskoe obshchestvo, 1999, 549 p. [In Russian]

21. Smirnova O. V., Zaugol'nova L. B., Khanina L. G., Bobrovskiy M. V., Korotkov V. N., Evstigneev O. I., Toropova N. A., Smirnov V. E., Shepeleva S. A., Pchelintseva O. V., Slavgorodskiy A. V., Glukhova E. M., Ponomarenko E. V., Esipova E. S., Ofman G. Yu., Romanovskiy A. M., Sarycheva E. P. Otsenka i sokhranenie bioraznoobraziya lesnogo pokrova $v$ zapovednikakh evropeyskoy Rossii [Evaluation and maintenance of biodiversity of forest cover in European Russian nature reserves]. Moscow: Nauchnyy mir, 2000, 196 p. [In Russian]

22. Evstigneev O. I., Murashev I. A., Romanov M. S. Russian Journal of Ecosystem Ecology. 2018, vol. 3 (1). DOI 10.21685/2500-0578-2018-1-1.

23. Evstigneev O. I., Solonina O. V. Russian Journal of Ecosystem Ecology. 2020, vol. 5 (1). DOI 10.21685/25000578-2020-1-3.

24. Onipchenko V. G. Funktsional'naya fitotsenologiya: Sinekologiya rasteniy: ucheb. posobie [Functional phytocenology: Plant synecology: textbook]. 2nd ed. Moscow: KRASAND, 2014, 576 p. [In Russian] 